\title{
PENDETEKSIAN KECURANGAN LAPORAN KEUANGAN MENGGUNAKAN METODE BENEISH RATIO INDEX PADA PERUSAHAAN MANUFAKTUR SUB SEKTOR KIMIA DAN FARMASI YANG TERDAFTAR DI BEI TAHUN 2016-2019
}

\author{
Firdaus Adi Sentari ${ }^{1}$, Fitriana ${ }^{2}$, Didin Saepudin ${ }^{3}$ \\ 1,2,3 Program Studi Magister Akuntansi,Universitas Sangga Buana YPKP Bandung \\ ${ }^{1}$ korespondensi : firdausadisentari@gmail.com
}

\begin{abstract}
Cases of financial statement fraud that occur in the world continue to increase, as well as in Indonesia. The fraud that occurs has a major impact on the company and for other users of financial statements. Therefore we need a detection tool that can be used to determine the possibility of committing fraud as an effort to reduce losses arising from the fraud, one of which is the Beneish Ratio Index method. This study was conducted to describe and test the relationship between the Days Sales Receivable Index (DSRI), Gross Margin Index (GMI), Asset Quality Index (AQI), Sales Growth Index (SGI) and Depreciation Index (DEPI) which became the Beneish Ratio Index variable for detection financial statement fraud in chemical and pharmaceutical sub-sector manufacturing companies listed on the IDX in 2016-2019. The research method used is descriptive and verification methods. The data analysis technique uses logistic regression analysis using SPSS 21 software. The results of the study prove that: (1) On average, the companies that became the research sample had poor conditions for the variables DSRI, GMI, AQI, SGI and DEPI; (2) The higher the DSRI, GMI, AQI, SGI and DEPI, the higher the detection of financial statements fraud; (3) The high and low DSRI has no effect on the detection of financial statements fraud; (4) The higher the GMI, the higher the detection of financial statements fraud; (5) The high and low AQI has no effect on the detection of financial statements fraud; (6) The higher the SGI, the higher the detection of financial statements fraud; (7) The high and low DEPI has no effect on the detection of financial statements fraud.
\end{abstract}

Keywords: Financial Statement Fraud and Beneish Ratio Index Method

\begin{abstract}
ABSTRAK
Kasus kecurangan laporan keuangan ( $f r a u d$ ) yang terjadi di dunia terus mengalami peningkatan, begitu juga di Indonesia. Kecurangan yang terjadi memberikan dampak yang besar bagi perusahaan maupun bagi pengguna laporan keuangan lainnya. Maka dari itu diperlukan suatu alat deteksi yang bisa digunakan untuk mengetahui kemungkinan dilakukannya tindakan fraud sebagai upaya mengurangi kerugian yang timbul akibat kecurangan tersebut, salahsatunya metode Beneish Ratio Index. Penelitian ini dilakukan untuk mendeskripsikan dan menguji pengaruh Days Sales Receivable Index (DSRI), Gross Margin Index (GMI), Asset Quality Index (AQI), Sales Growth Index (SGI) dan Depreciation Index (DEPI) yang menjadi variabel Beneish Ratio Index terhadap pendeteksian kecurangan laporan keuangan (fraud) pada perusahaan manufaktur sub sektor kimia dan farmasi yang terdaftar di BEI tahun 2016-2019. Metode penelitian yang digunakan adalah metode deskriptif dan verifikatif. Teknik analis data menggunakan analisis regresi logistik dengan menggunakan software SPSS 21. Hasil penelitian membuktikan bahwa: (1) Rata-rata perusahaan yang menjadi sampel penelitian memiliki kondisi DSRI, GMI, AQI, SGI dan DEPI yang kurang baik; (2) Semakin tinggi DSRI, GMI, AQI, SGI dan DEPI maka semakin tinggi terdeteksinya kecurangan laporan keuangan; (3) Tinggi rendahnya DSRI tidak ada pengaruhnya terhadap terdeteksinya kecurangan laporan keuangan; (4) Semakin tinggi GMI maka semakin tinggi terdeteksinya kecurangan laporan keuangan; (5) Tinggi rendahnya AQI tidak ada pengaruhnya terhadap terdeteksinya kecurangan laporan keuangan; (6) Semakin tinggi SGI maka semakin tinggi terdeteksinya kecurangan laporan keuangan; (7) Tinggi rendahnya DEPI tidak ada pengaruhnya terhadap terdeteksinya kecurangan laporan keuangan.
\end{abstract}

Kata kunci: Kecurangan Laporan Keuangan (fraud) dan Metode Beneish Ratio Index

\section{PENDAHULUAN}

Laporan keuangan merupakan laporan yang

berisi informasi keuangan suatu perusahaan yang ditampilkan secara terstruktur. Secara umum, laporan keuangan dibuat untuk memberikan informasi tentang posisi 
keuangan, kinerja keuangan, dan arus kas suatu entitas. Informasi ini berguna bagi sebagian besar pengguna laporan keuangan, baik pihak intern untuk keperluan membuat keputusan ekonomi, sekaligus menunjukan pertanggungjawaban atas penggunaan sumber daya yang dipercayakan. Adapun bagi pihak ekstern digunakan apabila entitas memiliki rencana untuk menarik perhatian investor, keperluan perbankan, dan lain sebagainya.

Laporan keuangan sebagai media untuk mengetahui informasi keuangan harus bebas dari kekeliruan (error) ataupun kecurangan (fraud) agar tidak menyesatkan pengguna laporan keuangan. Banyak kasus kecurangan yang terjadi dalam pengelolaan laporan keuangan. Lemahnya pengendalian internal menyebabkan besarnya peluang melakukan praktik kecurangan di berbagai level tingkatan manajemen. Standar Profesional Akuntan Publik (SPAP) pada Pernyataan Standar Akuntansi (PSA) No. 70 tentang Pertimbangan Atas Kecurangan Dalam Audit Laporan Keuangan menyebutkan bahwa kecurangan laporan keuangan sebagai salah saji atau penghilangan secara sengaja jumlah atau pengungkapan dalam laporan keuangan untuk mengelabui pemakai laporan keuangan dan efek yang timbul adalah ketidaksesuaian laporan keuangan dalam semua hal yang material dengan prinsif akuntansi berterima umum.

Berdasarkan hasil survey Association of Certified Fraud Examiners (ACFE) dalam Report to The Nations (RTTN) yang merupakan laporan dua tahunan yang dibuat
ACFE tentang fraud menunjukan bahwa kasus kecurangan laporan keuangan di dunia terus mengalami peningkatan. Hasil survey ACFE [1] terhadap 2.690 kasus kecurangan dari 125 negara di dunia menyatakan bahwa tindak kecurangan laporan keuangan memberikan dampak kerugian yang besar bagi perusahan maupun bagi pengguna laporan keuangan. Kecurangan yang dilakukan selain berdampak pada penyajian informasi laporan keuangan menjadi tidak relevan, informasi yang yang dihasilkan juga menjadi tidak dapat diandalkan. Meskipun sudah banyak ditemukannya kasus fraud yang terungkap dan merugikan, namun tindakan ini masih ramai dilakukan baik di sektor publik maupun sektor swasta.

Dalam RTTN Global Study on Occupationan Fraud and Abuse Asia-Pacific Edition tahun 2018 dapat dilihat bahwa Indonesia menduduki posisi 3 terbesar se-Asia Pasifik setelah Cina dan Australia dengan jumlah 29 dari total 220 kasus. Angka ini menunjukan bahwa masalah fraud atau tindak kecurangan di Indonesia harus benar-benar mendapatkan perhatian khusus. Lebih lanjut, hasil analisis dan survey yang dibuat ACFE tahun 2019, tindak kecurangan yang paling banyak terjadi di Indonesia yaitu $64,4 \%$ berupa korupsi, 28,9\% berupa fraud terhadap aset, dan 6,7\% berupa fraud terhadap laporan keuangan. ACFE tahun 2018 mencatat departemen kerja pelaku kecurangan dilakukan paling tinggi dilakukan oleh departemen operasional $24,3 \%$, yang secara berurutan diikuti oleh bagian keuangan 19,2\%, pembelian 18,8\%, pemasaran dan distribusi $17,2 \%$, manajemen 
puncak $12,6 \%$, akuntansi 2,9\%, pengawas dan audit intenal 1,7\%, dan 3,2\% departemen kerja pelaku lainnya. Dengan hasil survey tersebut menjadikan Indonesia sebagai salah satu negara dengan kategori korupsi yang tinggi menurut data Corruption Perception Index 2018 yang dilakukan oleh Transparency International pada tahun 2019, Indonesia menempati posisi 85 dari 180 negara di dunia dengan skor 40 skala 0-100 (0 berarti sangat buruk, dan 100 berarti sangat baik) [1].

Kasus kecurangan pada laporan keuangan sudah bukan hal yang biasa di Indonesia. Salahsatu skandal yang baru terungkap pada tahun 2019 dialami oleh PT Garuda Indonesia, diketahui bahwa PT Garuda Indonesia telah memanipulasi laporan keuangannya dengan melakukan kontrak bersama PT Mahata Aero Teknologi atas pemasangan peralatan layanan konektifitas dan hiburan selama 15 tahun sejak tanggal 26 Desember 2018. Sebesar USD 239,94 juta diakui nilai kontraknya dan bersifat piutang oleh pimpinan PT Garuda Indonesia sebagai laba yang justru harusnya rugi sebesar USD 175 juta. Fakta ini diketahui setelah komisaris PT Garuda Indonesia Chairul Tanjung dan Donny Oskaria menolak menandatangani laporan keuangan tahun 2018. Kejanggalan baru diketahui pasca RUPST yang terlihat pada akun pendapatan di laporan laba rugi 2018, perusahaan mencatatat laba bersih senilai USD 809.846. Keadaan ini jelas sangat berbeda dengan tahun 2017 yang masih merugi senilai USD 216.582 .416 [2].
Kasus kecurangan laporan keuangan lainnya pernah juga terjadi pada sektor farmasi, yakni pada PT Kimia Farma pada audit tahun buku 31 Desember 2001. Manajemen PT Kimia Farma melaporkan adanya laba bersih sebesar Rp 132 miliar dan telah diaudit oleh Kantor Akuntan Publik (KAP) Hans Tuanakotta \& Mustofa (HTM), namun laporan yang tersaji dicurigai mengandung unsur rekayasa sehinga kementerian BUMN meminta dilakukannya audit ulang, dan hasilnya laba bersih yang tercantum hanya sebesar Rp 99,56 miliar atau lebih rendah sebesar Rp 32,6 miliar (24,7\%) dari laba awal yang dilaporkan [3].

Kinerja positif diraih perusahaan manufaktur sub sektor kimia dan farmasi pada tahun 2020. Kedua sektor ini merupakan sektor yang tetap tumbuh baik dari nilai pasar maupun nilai investasinya di tengah kondisi ekonomi saat ini. Hal ini mengundang ketertarikan investor karena berharap keuntungan yang akan didapat atas dana yang ditanamnya mendapat pengembalian atau deviden yang besar. Manajemen perusahaan memegang tanggungjawab yang besar atas kepercayaan yang diberikan investor, karena apabila manajemen mampu mendongkrak performa perusahaan dan target yang diberikan tercapai akan mendapatkan komisi yang besar. Namun ketika hasil kinerja perusahaan tidak mencapai target yang ditentukan, kemungkinan tindakan manipulasi laporan keuangan bisa dilakukan supaya target yang ditentukan oleh pihak eksekutif seolah-olah tercapai. Tindakan ini membuat penyajian informasi bagi pengguna 
laporan keuangan sudah tidak sesuai dengan kondisi yang sebenarnya.

Penelitian mengenai pendeteksian kecurangan pada laporan keuangan menggunakan metode Beneish atau Beneish Ratio Index sebelumnya dilakukan oleh Venny Suheni dan Muhammad Faisal Arif (2020) dengan objek penelitian perusahaan manufaktur yang terdaftar di BEI tahun 2017-2018 menunjukan hasil penelitian bahwa Days Sales In Receivable Index, Gross Margin Index, Asset Quality Index, Sales Growth Index, Depreciation Index, Sales General And Administrative Expenses Index, Leverage Index, dan Total Accrual To Total Assets Index masing-masing tidak berpengaruh terhadap kecurangan laporan keuangan; Serta penelitian yang dilakukan oleh Fernanda Kusuma I.P (2017) dengan objek penelitian perusahaan manufaktur yang terdaftar di BEI periode 2011-2015 dengan hasil penelitian bahwa Days Sales In Receivable Index, Gross Margin Index, Asset Quality Index, Sales Growth Index, Leverage Index, Total Accrual To Total Assets Index memberikan pengaruh terhadap pendeteksian fraud. Sedangkan Depreciation Index dan Sales General And Administrative Expenses Index tidak memberikan pengaruh terhadap pendeteksian fraud.

Penelitian ini penting untuk diteliti karena menggunakan variabel yang dapat mengungkapkan adanya kemungkinan dilakukannya kecurangan (fraud) pada perusahaan atau pendapatan yang dicatat dalam laporan keuangan [4]. Alasan penulis menggunakan perusahaan manufaktur sub- sektor kimia dan farmasi karena pada perusahaan manufaktur terdapat banyak tahap dalam proses bisnisnya, sehingga peluang untuk melakukan kecurangan sangat besar. Selain itu, sektor kimia dan farmasi merupakan salah satu sektor usaha yang terus mengalami pertumbuhan, prosfek perusahaan kimia dan farmasi diprediksi akan semakin berkembang pesat baik sekarang maupun di masa yang akan datang. Investor melihat peluang yang menarik bahwa investasi di sektor kimia dan farmasi termasuk salah satu investasi yang cukup menjanjikan di masa depan. Variabel penelitian juga menggunakan 5 alat deteksi metode Beneish Ratio Index yakni Days Sales In Receivable Index (DSRI), Gross Margin Index (GMI), Asset Quality Index (AQI), Sales Growth Index (SGI) dan Depreciation Index (DEPI). Penelitian ini bertujuan untuk mendeskripsikan dan menguji pengaruh Days Sales Receivable Index (DSRI), Gross Margin Index (GMI), Asset Quality Index (AQI), Sales Growth Index (SGI) dan Depreciation Index (DEPI) yang menjadi variabel Beneish Ratio Index terhadap pendeteksian kecurangan laporan keuangan (fraud). Diharapkan penelitian ini dapat menambah literatur di bidang fraud dengan pendekatan lima model Beneish Ration Index.

\section{TINJAUAN PUSTAKA}

\section{Agency Theory (Teori Keagenan)}

Agency theory (teori keagenan) merupakan cabang dari game theory (teori permainan) yang mempelajari skema dari kontrak untuk 
memotivasi agent yang rasional agar bertindak sesuai keinginan principal [5].

Teori keagenan merupakan suatu konsep yang menggambarkan hubungan principal (pemberi kontrak) dengan agen (penerima kontrak, pemberi kontrak memberikan wewenang berupa pengambilan keputusan kepada penerima kontrak demi kepentingan dan mencapai tujuan [6].

\section{Fraud (kecurangan)}

Fraud (kecurangan) merupakan istilah umum yang memuat berbagai jenis arti dimana kecerdasan baik individu/kelompok dapat menjadi alat yang dipilih individu/kelompok tersebut untuk mendapatkan keuntungan dari pihak lain dengan representasi yang salah[7] Kecurangan adalah segala bentuk tindakan illegal yang disinyalir dengan trik berupa tipu daya, penyembunyian atau pelanggaran kepercayaan. Perbuatan ini tidak hanya terbatas pada tindakan berupa ancaman kekerasan verbal maupun kekerasan fisik. Kecurangan dilakukan baik perorangan maupun organisasi untuk memperoleh keuntungan finansial ataupun keuntungan dari jasa; atau bahkan untuk mengamankan keuntungan bisnis pribadi [8].

\section{Financial Statement (laporan keuangan)}

Laporan keuangan merupakan suatu alat yang berguna untuk mendapatkan informasi terkait posisi keuangan atau neraca perusahaan beserta hasil yang dicapai oleh perusahaan yang bersangkutan [9].

Laporan keuangan merupakan ringkasan tertulis yang menginformasikan kegiatan bisnis dan kinerja keuangan perusahaan yang difungsikan oleh pihak internal ataupun eksternal yang juga dibutuhkan oleh investor dan kreditor untuk mengevaluasi kondisi perusahaan [10].

\section{Financial Statement Fraud (kecurangan laporan keuangan)}

Kecurangan laporan keuangan merupakan bentuk penipuan terutama pada top to down yang berdampak negatif pada individu, organisasi dan masyarakat [11]

Kecurangan laporan keuangan adalah representasi yang keliru tentang kondisi keuangan suatu perusahaan dicapai melalui penyajian yang disengaja dibuat keliru atau berupa penambahan atau pengurangan jumlah yang diungkapkan dalam laporan keuangan untuk menipu pengguna laporan keuangan [12].

\section{Metode Beneish Ratio Index}

Beneish M-Score merupakan teknik yang dikembangkan oleh Messod D. Beneish (1999) terkait dengan perubahan aset dan pertumbuhan penjualan yang dirumuskan dalam teknik tersebut berupa skor atau nilai yang merefleksikan terjadinya manipulasi pada laba. Manfaat dari model Beneish Ratio Index yakni penggunan laporan keuangan dapat mendeteksi tindak kecurangan laporan keuangan melalui nilai dari akun-akun yang terdapat dalam laporan keuangan, sehingga dapat membedakan mana laporan keuangan yang terindikasi melakukan fraud dan non fraud lebih dini. Berikut formula Beneish $M$ Score: 
Model 1 - Beneish Model 8 Variabel:

Beneish M-Score $=-4,840+0,920 D S R I+$ $0,528 G M I+0,404 A Q I+0,892 S G I+$ 0,115DEPI - 0,172SGAI - 0,327LVGI + 4,697TATA

Model 2 - Beneish Model 5 Variabel:

Beneish M-Score $=-6,065+0,823 D S R I+$ $0,906 G M I+0,593 A Q I+0,717 S G I+$ 0,107DEPI

Beneish mengungkapkan umumnya kecurangan (fraud) atau manipulasi laba ditunjukan dengan peningkatan atas pendapatan atau penurunan atas beban perusahaan dari satu tahun ke tahun sebelumnya. Jika hasil Beneish M-Score lebih besar dari -2.22, maka dikategorikan sebagai perusahaan yang melakukan kecurangan atau fraud. Sedangkan jika hasilnya lebih kecil dari -2.22 , dikategorikan sebagai perusahaan yang tidak melakukan kecurangan atau non fraud.

\section{a. Days Sales In Receivable Index (DSRI)}

DSRI merupakan nilai yang dihasilkan dari perhitungan rasio penjualan harian dalam piutang pada tahun pertama dimana manipulasi laba ditemukan dengan ukuran yang sesuai pada tahun sebelumnya. DSRI menilai apakah piutang dan pendapatan sudah berada pada titik keseimbangan antara dua tahun berturut-turut. Jumlah yang besar dalam DSRI dapat berarti merupakan akibat dari perubahan kebijakan kredit untuk memacu penjualan dalam menghadapi persaingan yang meningkat, tetapi peningkatan yang tidak proporsional dalam piutang juga dapat dipengaruhi inflasi [13]. DSRI dapat dihitung dengan rumus berikut:

DSRI $=\frac{\text { Net Receivables }(t) / \operatorname{Sales}(t)}{\text { Net Receivables }(t-1) / \operatorname{Sales}(t-1)}$

Jika DSRI lebih besar dari 1 hal ini menunjukan adanya peningkatan atas jumlah piutang usaha yang dimiliki. Kondisi tersebut mengindikasikan perusahaan mengalami kenaikan yang besar pada DSRI pada periode perhitungan yakni merupakan hasil dari perubahan dalam kebijakan kredit untuk meningkatkan penjualan, tetapi ketidakseimbangan peningkatan pada piutang secara wajar terhadap penjualan dapat memungkinkan adanya lonjakan pendapatan. Sehingga kenaikan yang besar pada variabel ini memiliki keterkaitan dengan kemungkinan pencatatan penjualan dan pendapatan yang terlalu besar.

\section{b. Gross Margin Index (GMI)}

GMI adalah rasio margin laba kotor pada tahun sebelumnya terhadap margin laba tahun berjalan. Jika GMI lebih besar dari 1, ini menandakan negatif bagi masa depan perusahaan. Apabila perusahaan memiliki masa depan negatif, maka manajer perusahaan terdorong untuk memanipulasi laba [13]. GMI dapat dihitung dengan rumus berikut:

$$
=\frac{(\text { Sales }(t-1)-\text { Cost of Good Sold }(t-1)) / \text { Sales }(t-1)}{(\text { Sales }(t)-\text { Cost of Good Sold }(t)) / \text { Sales }(t)}
$$

Jika nilai rasio GMI lebih dari 1 itu petanda yang negatif terhadap prosfek perusahaan karena menunjukan terjadinya penurunan atas laba kotor perusahaan. Jadi, jika 
perusahaan dengan prosfek kerja yang buruk maka akan lebih banyak terdapat manipulasi.

\section{c. Asset Quality Index (AQI)}

AQI yaitu rasio yang membandingkan aset tidak lancar yang dimiliki oleh perusahaan kecuali aset tetap dengan total aset perusahaan pada suatu periode dengan periode sebelumnya. AQI menunjukan kualitas aset tidak lancar yang dimiliki perusahaan yang kemungkinan akan memberikan manfaat bagi perusahaan di masa depan [13]. AQI dapat dihitung dengan rumus berikut:

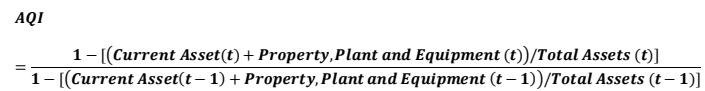

Jika AQI lebih besar dari 1 menunjukan terjadinya penurunan atas kualitas aset, karena peningkatan atas jumlah aset tidak lancar yang dapat memberikan manfaat di masa yang akan datang dan peningkatan jumlah beban yang ditangguhkan. Penangguha beban ini dimaksudkan agar perusahaan tidak mengalami pengurangan, karena beban yang ada pada aset tidak lancar selain aset tetap dapat mengurangi pendapatan. Maka jika semakin tinggi rasio AQI, maka diyakini perusahaan telah melakukan peningkatan biaya tangguhan dengan kata lain melakukan memanipulasi pendapatan (fraud).

\section{d. Sales Growth Index (SGI)}

SGI adalah rasio yang menilai tingkat pertumbuhan penjualan perusahaan. Apabila skornya lebih besar dari 1 menunjukan bahwa penjualan mengalami peningkatan dari tahun sebelumnya. Perusahaan yang mengalami pertumbuhan penjualan lebih cenderung untuk melakukan manipulasi pendapatan [13]. SGI dapat dihitung dengan rumus berikut:

$S G I=\frac{\operatorname{Sales}(t)}{\operatorname{Sales}(t-1)}$

Jika rasio SGI untuk mendeteksi kecurangan pada laporan keuangan dapat dilihat apabila nilai SGI lebih dari 1, maka ini mengindikasikan terjadinya peningkatan atas penjualan, sedangkan penurunan atas rasio ini menunjukkan adanya penurunan atas penjualan.

\section{e. Depreciation Index (DEPI)}

DEPI merupakan variabel yang menyandingkan beban penyusutan terhadap aktiva tetap sebelum penyusutan pada periode berjalan dan periode sebelumnya. DEPI dapat dihitung dengan rumus berikut: DEPI

$=\frac{\text { Depreciation }(t-1) /(P P E(t-1)+\text { Depreciation }(t-1))}{\text { Depreciation }(t) /(P P E(t)+\text { Depreciation }(t))}$

Jika rasio DEPI diatas bahwa untuk menggunakan rasio tersebut dalam mendeteksi kecurangan pada laporan keuangan dapat dilihat apabila nilai rasio DEPI lebih dari 1, mengindikasikan bahwa terjadinya penurunan atas depresiasi aktiva tetap dengan kata lain mengindikasikan terjadinya earning overstatement.

Penelitian tentang pendeteksian kecurangan laporan keuangan menggunakan metode Beneish Ratio Index telah banyak dilakukan 
dengan hasil yang beragam, seperti yang dilakukan Venny Suheni dan Muhammad Faisal Arif (2020) pada perusahaan manufaktur, Rima Novi Kartikasari dan Gugus Irianto (2010) pada perusahaan yang terdaftar di BEI, Hantono (2018) pada perusahaan BUMN, Fernanda Kusuma I.P (2017) pada perusahaan manufaktur dan Setyarini Santosa dan Josep Ginting (2019) pada perusahaan yang terdapat di OJK. Sedangkan penelitian ini yakni pendeteksian kecurangan laporan keuangan menggunakan metode Beneish Ratio Index pada perusahaan manufaktur sub-sektor kimia dan farmasi tahun 2016-2019. Tujuannya untuk menemukan jawaban dari penelitianpenelitian terdahulu yang bertentangan.

\section{METODE PENELITIAN}

Metode yang digunakan dalam penelitian ini adalah metode deskriptif dan verifikatif dengan pendekatan kuantitatif. Populasi yang digunakan dalam penelitian sebanyak 22 perusahaan yang terdaftar di BEI yang diakses di website www.idx.com tahun 20162019. Teknik pengambilan sampel yang digunakan dalam penelitian yakni purposive sampling menjadi sebanyak 18 perusahaan. Data yang diolah sebanyak 72 laporan keuangan perusahaan (sampel perusahaan $\mathrm{x}$ tahun pengamatan). Teknik analisis data yang digunakan dalam penelitian ini adalah analisis regresi logistik, karena variabel bebasnya berbentuk dummy dan berskala nominal. Langkah-langkah yang dilakukan diantaranya Uji Kelayakan Model Regresi (Goodness of Fit Test), Uji Kelayakan
Keseluruhan Model (Overall Model Fit Test), Koefisien Determinasi (Nagelkerke $R$ Square), Uji Signifikansi Model Secara Simultan sampai akhirnya Persamaan Regresi Logistik. Persamaan model regresi logistik yang digunakan adalah sebagai berikut:

$\operatorname{Fraud}(\mathrm{Y})=\beta 0+\beta 1 D S R I+\beta 2 G M I+$

$\beta 3 A Q I+\beta 4 S G I+\beta 5 D E P I+\varepsilon i$

\section{HASIL DAN PEMBAHASAN}

\section{Hasil Penelitian}

\section{Statistik Deskriptif}

Hasil analisis menunjukan bahwa:

1. Fraud atau kecurangan laporan keuangan (Variabel Y) diukur dengan variabel dummy. Hasil sampel perusahaan yang terdeteksi melakukan kecurangan laporan keuangan atau fraud adalah 1, sedangkan yang tidak terdeteksi melakukan fraud adalah 0. Nilai mean yang diperoleh dari variabel ini sebesar 0,1528 ;

2. DSRI atau Days Sales In Receivable Index (Variabel $\mathrm{X}_{1}$ ) memiliki nilai terendah sebesar 0,27 yang dimiliki oleh Eterindo Wahanatama Tbk pada tahun 2018. Nilai terbesar sebesar 1,98 yang dimiliki oleh Chandra Asri Petrochemical Tbk pada tahun 2016. Nilai mean sebesar 1,0820 dan Nilai standar deviasi sebesar 0,303349 .

3. GMI atau Gross Margin Index (Variabel $\mathrm{X}_{2}$ ) memiliki nilai terendah sebesar 0,31 yang dimiliki oleh Eterindo Wahanatama Tbk pada tahun 2019. Nilai terbesar sebesar 10,76 yang dimiliki oleh Eterindo Wahanatama Tbk pada tahun 2016. Nilai 
mean sebesar 1,3154 dan Nilai standar deviasi sebesar 1,53469.

4. AQI atau Asset Quality Index (Variabel $\mathrm{X}_{3}$ ) memiliki nilai terendah sebesar $-0,52$ yang dimiliki oleh Industri Jamu \& Farmasi Sido Muncul Tbk pada tahun 2019. Nilai terbesar sebesar 96,54 yang dimiliki oleh Barito Pacific Tbk pada tahun 2018. Nilai mean sebesar 2,3182 dan Nilai standar deviasi sebesar 11,27399 .

5. SGI atau Sales Growth Index (Variabel $\mathrm{X}_{4}$ ) memiliki nilai terendah sebesar 0,21 yang dimiliki oleh Eterindo Wahanatama Tbk pada tahun 2017. Nilai terbesar sebesar 9,37 yang dimiliki oleh Eterindo Wahanatama Tbk pada tahun 2019. Nilai mean sebesar 1,1759 dan Nilai standar deviasi sebesar 0,99780.

6. DEPI atau Depreciation Index (Variabel $\mathrm{X}_{5}$ ) memiliki nilai terendah sebesar 0,07 yang dimiliki oleh Emdeki Utama Tbk pada tahun 2017. Nilai terbesar sebesar 6,64 yang dimiliki oleh Emdeki Utama Tbk pada tahun 2019. Nilai mean sebesar 1,0573 dan Nilai standar deviasi sebesar 0,69520 .

\section{Uji Kelayakan Model Regresi (Goodness of} Fit Test)

Hasil pengujian menunjukan hasil pengujian Hosmer and Lemeshow dapat diketahui nilai Chi-square hitung sebesar $0,384<$ nilai $C h i$ square tabel sebesar 9,488 dengan tingkat signifikansi sebesar 1,00>0,05. Maka $\mathrm{H}_{0}$ diterima yang berarti bahwa pada model logistik yang digunakan fit dengan data atau model dapat diterima karena cocok dengan data observasinya sehingga model ini dapat digunakan untuk analisis selanjutnya.

\section{a) Uji Kelayakan Keseluruhan Model}

\section{(Overall Model Fit Test)}

Hasil dari pengujian menunjukan hasil pengujian kelayakan keseluruhan model dengan perbandingan nilai -2Log Likelihood awal (block number $=0$ ) dengan -2Log Likelihood akhir (block number $=1$ ) adalah 62,614 untuk nilai awal dan setelah variabel independen dimasukan pada model regresi, maka nilai -2Log Likelihood akhir (block number $=1$ ) adalah sebesar 37,431. Hal ini berarti bahwa model layak digunakan. Adanya pengurangan nilai antara $-2 \log$ Likelihood awal dengan nilai $-2 \log$ Likelihood akhir menunjukan bahwa model yang dihipotesiskan "fit" dengan data.

\section{Koefisien Determinasi (Nagelkerke $R$ Square)}

Hasil pengujian menunjukan hasil pengujian koefisien determinasi yang dilihat dari nilai statistik Nagelkerke $R$ Square adalah 0,912 yang artinya variabel dependen (kecurangan laporan keuangan atau fraud) dapat dijelaskan oleh variabel independen (DSRI, GMI, AQI, SGI dan DEPI) sebesar 91,2\%, sedangkan sisanya sebesar $8,8 \%$ dijelaskan oleh variabel-variabel lain di luar model penelitian.

\section{Uji Signifikansi Model Secara Simultan (Omnibus Test)}

Hasil dari pengujian menunjukan hasil pengujian signifikansi model secara simultan 
diketahui memiliki nilai Chi-square hitung sebesar 53,433 > nilai Chi-square tabel sebesar 11,070 dengan tingkat signifikansi sebesar $0,000<0,05$ berarti $\mathrm{H}_{1}$ berhasil membuktikan bahwa DSRI, GMI, AQI, SGI dan DEPI secara simultan mempunyai pengaruh yang signifikan terhadap kecurangan laporan keuangan atau fraud.

\section{Model Persamaan Regresi Logistik}

Hasil dari pengujian menunjukan model persamaan regresi logistik dalam penelitian ini adalah sebagai berikut:

\section{Fraud $(Y)=-23,271+4,715(D S R I)+$ 9,339(GMI)+ $\quad 4,045(\mathrm{AQI})+1,916(\mathrm{SGI})+$ \\ 3,302(DEPI)}

Dari model persamaan regresi logistik tersebut dapat dijelakan sebagai berikut:

a. Konstanta sebesar -23,27 menunjukan bahwa jika semua variabel independen penelitian bernilai nol, maka fraud atau nilai beneish ratio index akan bernilai sebesar $-23,271$.

b. Variabel DSRI (Days Sales In Receivable Index) menunjukan koefisien regresi positif sebesar 4,715 artinya setiap penambahan satu (variabel lain dianggap konstan) akan menaikan DSRI sebesar 4,715 satuan dengan nilai signifikansi sebesar 0,320 lebih besar dari taraf signifikansi yaitu 0,050 atau 5\%. Maka $\mathrm{H}_{2}$ tidak berhasil membuktikan bahwa DSRI ada pengaruh dengan pendeteksian kecurangan laporan keuangan (fraud);

c. Variabel GMI (Gross Margin Index) menunjukan koefisien regresi positif sebesar 9,339 artinya setiap penambahan satu (variabel lain dianggap konstan) akan menaikan GMI sebesar 9,339 satuan dengan nilai signifikansi sebesar 0,046 lebih kecil dari taraf signifikansi yaitu 0,050 atau 5\%. Maka $\mathrm{H}_{3}$ berhasil membuktikan bahwa GMI ada pengaruh dengan pendeteksian kecurangan laporan keuangan (fraud);

d. Variabel AQI (Asset Quality Index) menunjukan koefisien regresi positif sebesar 4,045 artinya setiap penambahan satu (variabel lain dianggap konstan) akan menaikan AQI sebesar 4,045 satuan dengan nilai signifikansi sebesar 0,073 lebih besar dari taraf signifikansi yaitu 0,050 atau $5 \%$. Maka $\mathrm{H}_{4}$ tidak berhasil membuktikan bahwa AQI ada pengaruh dengan pendeteksian kecurangan laporan keuangan (fraud);

e. Variabel SGI (Sales Growth Index) menunjukan koefisien regresi positif sebesar 1,916 artinya setiap penambahan satu (variabel lain dianggap konstan) akan menaikan SGI sebesar 1,916 satuan dengan nilai signifikansi sebesar 0,024 lebih kecil dari taraf signifikansi yaitu 0,050 atau 5\%. Maka $\mathrm{H}_{5}$ berhasil membuktikan bahwa SGI ada pengaruh dengan pendeteksian kecurangan laporan keuangan (fraud);

f. Variabel DEPI (Depreciation Index) menunjukan koefisien regresi positif sebesar 3,302 artinya setiap penambahan satu (variabel lain dianggap konstan) akan menaikan DEPI sebesar 3,302 satuan dengan nilai signifikansi sebesar 0,297 lebih besar dari taraf signifikansi yaitu 
0,050 atau 5\%. Maka $\mathrm{H}_{6}$ tidak berhasil membuktikan bahwa DEPI ada pengaruh dengan pendeteksian kecurangan laporan keuangan (fraud).

\section{Pembahasan}

\section{Analisis Deskriptif}

\section{Days Sales Receivable Index (DSRI)}

DSRI atau Days Sales In Receivable Index (Variabel $\mathrm{X}_{1}$ ) memiliki nilai terendah sebesar 0,27 yang dimiliki oleh Eterindo Wahanatama Tbk pada tahun 2018. Nilai terbesar sebesar 1,98 yang dimiliki oleh Chandra Asri Petrochemical Tbk pada tahun 2016. Nilai mean sebesar 1,0820 dan Nilai standar deviasi sebesar 0,303349. Dengan nilai standar deviasi yang lebih kecil dari nilai mean, maka nilai mean dapat digunakan sebagai representatif dari keseluruhan data.

\section{Gross Margin Index (GMI)}

GMI atau Gross Margin Index (Variabel $\mathrm{X}_{2}$ ) memiliki nilai terendah sebesar 0,31 yang dimiliki oleh Eterindo Wahanatama Tbk pada tahun 2019. Nilai terbesar sebesar 10,76 yang dimiliki oleh Eterindo Wahanatama Tbk pada tahun 2016. Nilai mean sebesar 1,3154 dan Nilai standar deviasi sebesar 1,53469. Dengan nilai standar deviasi yang lebih besar dari nilai mean, maka nilai mean tidak dapat digunakan sebagai representatif dari keseluruhan data.

\section{Asset Quality Index (AQI)}

AQI atau Asset Quality Index (Variabel $\mathrm{X}_{3}$ ) memiliki nilai terendah sebesar -0,52 yang dimiliki oleh Industri Jamu \& Farmasi Sido
Muncul Tbk pada tahun 2019. Nilai terbesar sebesar 96,54 yang dimiliki oleh Barito Pacific Tbk pada tahun 2018. Nilai mean sebesar 2,3182 dan Nilai standar deviasi sebesar 11,27399. Dengan nilai standar deviasi yang lebih besar dari nilai mean, maka nilai mean tidak dapat digunakan sebagai representatif dari keseluruhan data.

\section{Sales Growth Index (SGI)}

SGI atau Sales Growth Index (Variabel $\mathrm{X}_{4}$ ) memiliki nilai terendah sebesar 0,21 yang dimiliki oleh Eterindo Wahanatama Tbk pada tahun 2017. Nilai terbesar sebesar 9,37 yang dimiliki oleh Eterindo Wahanatama Tbk pada tahun 2019. Nilai mean sebesar 1,1759 dan Nilai standar deviasi sebesar 0,99780. Dengan nilai standar deviasi yang lebih kecil dari nilai mean, maka nilai mean dapat digunakan sebagai representatif dari keseluruhan data.

\section{Depreciation Index (DEPI)}

DEPI atau Depreciation Index (Variabel $\mathrm{X}_{5}$ ) memiliki nilai terendah sebesar 0,07 yang dimiliki oleh Emdeki Utama Tbk pada tahun 2017. Nilai terbesar sebesar 6,64 yang dimiliki oleh Emdeki Utama Tbk pada tahun 2019. Nilai mean sebesar 1,0573 dan Nilai standar deviasi sebesar 0,69520. Dengan nilai standar deviasi yang lebih kecil dari nilai mean, maka nilai mean dapat digunakan sebagai representatif dari keseluruhan data.

\section{Kecurangan Laporan Keuangan (fraud)}

Fraud atau kecurangan laporan keuangan (Variabel Y) diukur dengan variabel dummy. 
Hasil sampel perusahaan yang terdeteksi melakukan kecurangan laporan keuangan atau fraud adalah 1, sedangkan yang tidak terdeteksi melakukan fraud adalah 0 . Nilai mean yang diperoleh dari variabel ini sebesar 0,1528 yang artinya dari 72 laporan keuangan perusahaan manufaktur sub sektor kimia dan farmasi yang diteliti rata-rata terdeteksi melakukan kecurangan laporan keuangan (fraud) sebesar 15,28\% dengan standar deviasi sebesar 0,36230.

\section{Analisis Verifikatif}

Pengaruh Days Sales In Receivable (DSRI), Gross Margin Index (GMI), Asset Quality Index (AQI), Sales Growth Index (SGI) dan Depreciation Index (DEPI) dengan Pendeteksian Kecurangan Laporan Keuangan (fraud)

Hipotesis pertama $\left(\mathrm{H}_{1}\right)$ memprediksi semakin tinggi Days Sales In Receivable (DSRI), Gross Margin Index (GMI), Asset Quality Index (AQI), Sales Growth Index (SGI) dan Depreciation Index (DEPI) maka semakin tinggi terdeteksinya kecurangan laporan keuangan (fraud). $\mathrm{H}_{1}$ merupakan jawaban sementara untuk rumusan masalah nomor 2 (dua). Hasil uji hipotesis secara simultan yang dilakukan melalui uji omnibus test of model coefficients menunjukan dengan nilai Chi-square hitung sebesar 53,433 > nilah Chi-square tabel sebesar 11,070 dengan tingkat signifikansi sebesar $0,00<0,05$ yang berarti bahwa Days Sales In Receivable (DSRI), Gross Margin Index (GMI), Asset Quality Index (AQI), Sales Growth Index (SGI) dan Depreciation Index (DEPI) ada pengaruh positif dengan pendeteksian kecurangan laporan keuangan (fraud), dengan kata lain $\mathrm{H}_{1}$ dalam penelitian ini diterima atau variabel independen DSRI, GMI, AQI, SGI dan DEPI secara simultan dapat digunakan untuk mendeteksi kecurangan laporan keuangan (fraud).

\section{Pengaruh Days Sales In Receivable Index} (DSRI) denganPendeteksian Kecurangan Laporan Keuangan (fraud)

Hipotesis kedua $\left(\mathrm{H}_{2}\right)$ memprediksi semakin tinggi Days Sales In Receivable (DSRI) maka semakin tinggi terdeteksinya kecurangan laporan keuangan (fraud). $\mathrm{H}_{2}$ merupakan jawaban sementara untuk rumusan masalah nomor 3 (tiga). Hasil uji hipotesis menunjukan nilai koefisien regresi positif sebesar 4,715 dengan nilai signifikansi sebesar $0,320>$ taraf signifikansi sebesar 0,050 yang berarti bahwa Days Sales In Receivable Index (DSRI) tidak ada pengaruh positif dengan pendeteksian kecurangan laporan keuangan (fraud). Dengan kata lain $\mathrm{H}_{2}$ dalam penelitian ini ditolak yang berarti variabel independen DSRI tidak dapat digunakan untuk mendeteksi kecurangan laporan keuangan (fraud).

\section{Pengaruh Gross Margin Index (GMI) dengan Pendeteksian Kecurangan Laporan Keuangan (fraud)}

Hipotesis ketiga $\left(\mathrm{H}_{3}\right)$ memprediksi semakin tinggi Gross Margin Index (GMI) maka semakin tinggi terdeteksinya kecurangan laporan keuangan (fraud). $\mathrm{H}_{3}$ merupakan jawaban sementara untuk rumusan masalah 
nomor 4 (empat). Hasil uji hipotesis menunjukan nilai koefisien regresi positif sebesar 9,339 dengan nilai signifikansi sebesar $0,046<$ taraf signifikansi sebesar 0,050 yang berarti bahwa Gross Margin Index (GMI) ada pengaruh positif dengan pendeteksian kecurangan laporan keuangan (fraud), dengan kata lain $\mathrm{H}_{3}$ dalam penelitian ini diterima atau variabel independen GMI dapat digunakan untuk mendeteksi kecurangan laporan keuangan (fraud).

\section{Pengaruh Asset Quality Index (AQI) dengan Pendeteksian Kecurangan Laporan Keuangan (fraud)}

Hipotesis keempat $\left(\mathrm{H}_{4}\right)$ memprediksi semakin tinggi Asset Quality Index (AQI) maka semakin tinggi terdeteksinya kecurangan laporan keuangan (fraud). $\mathrm{H}_{4}$ merupakan jawaban sementara untuk rumusan masalah nomor 5 (lima). Hasil uji hipotesis menunjukan nilai koefisien regresi positif sebesar 4,045 dengan nilai signifikansi sebesar $0,073>$ taraf signifikansi sebesar 0,050 yang berarti bahwa Asset Quality Index (AQI) tidak ada pengaruh positif dengan pendeteksian kecurangan laporan keuangan (fraud). Dengan kata lain $\mathrm{H}_{4}$ dalam penelitian ini ditolak atau variabel independen AQI tidak dapat digunakan untuk mendeteksi kecurangan laporan keuangan (fraud).

\section{Pengaruh Sales Growth Index (SGI) dengan Pendeteksian Kecurangan}

\section{Laporan Keuangan (fraud)}

Hipotesis kelima $\left(\mathrm{H}_{5}\right)$ memprediksi semakin tinggi Sales Growth Index (SGI) maka semakin tinggi terdeteksinya kecurangan laporan keuangan (fraud). $\mathrm{H}_{5}$ merupakan jawaban sementara untuk rumusan masalah nomor 6 (enam). Hasil uji hipotesis menunjukan nilai koefisien regresi positif sebesar 1,916 dengan nilai signifikansi sebesar $0,024<$ taraf signifikansi sebesar 0,050 yang berarti bahwa Sales Growth Index (SGI) ada pengaruh positif dengan pendeteksian kecurangan laporan keuangan (fraud), dengan kata lain $\mathrm{H}_{5}$ dalam penelitian ini diterima atau variabel independen SGI dapat digunakan untuk mendeteksi kecurangan laporan keuangan (fraud).

\section{Pengaruh Depreciation Index (DEPI) dengan Pendeteksian Kecurangan}

\section{Laporan Keuangan (fraud)}

Hipotesis keenam $\left(\mathrm{H}_{6}\right)$ memprediksi semakin tinggi Depreciation Index (DEPI) maka semakin tinggi terdeteksinya kecurangan laporan keuangan (fraud). $\mathrm{H}_{6}$ merupakan jawaban sementara untuk rumusan masalah nomor 7 (tujuh). Hasil uji hipotesis menunjukan nilai koefisien regresi positif sebesar 3,302 dengan nilai signifikansi sebesar 0,297 > taraf signifikansi sebesar 0,050 yang berarti bahwa Depreciation Index (DEPI) tidak ada pengaruh positif dengan pendeteksian kecurangan laporan keuangan (fraud). Dengan kata lain $\mathrm{H}_{6}$ dalam penelitian ini ditolak atau variabel independen DEPI tidak dapat digunakan untuk mendeteksi kecurangan laporan keuangan (fraud). 


\section{KESIMPULAN DAN SARAN}

\section{Kesimpulan}

Hasil dari penelitian dan pembahasan dari penelitian yaitu kondisi DSRI (Days Sales In Receivable Index), GMI (Gross Margin Index), AQI (Asset Quality Index), SGI (Sales Growth Index), DEPI (Depreciation Index) dan Beneish Ratio Index (pendeteksian fraud) dalam kondisi kurang baik. Hal ini ditandai dengan rata-rata perusahaan menunjukan adanya peningkatan atas jumlah piutang usaha yang dimiliki, ratarata perusahaan menunjukan terjadinya penurunan atas laba kotor perusahaan, ratarata perusahaan menunjukan terjadinya penurunan atas kualitas aset, rata-rata perusahaan menunjukan adanya peningkatan atas penjualan dari tahun sebelumnya, ratarata perusahaan menunjukan penurunan atas depresiasi aktiva tetap dan terdapat 6 perusahaan terindikasi melakukan kecurangan laporan keuangan (fraud).

Pengaruh DSRI (Days Sales In Receivable Index), GMI (Gross Margin Index), AQI (Asset Quality Index), SGI (Sales Growth Index) dan DEPI (Depreciation Index) secara simultan atau secara bersamaan menunjukan mempunyai pengaruh yang signifikan terhadap pendeteksian kecurangan laporan keuangan atau fraud. Pengaruh GMI (Gross Margin Index) dan AQI (Asset Quality Index) secara parsial atau secara masing-masing menunjukan mempunyai pengaruh yang signifikan terhadap pendeteksian kecurangan laporan keuangan atau fraud. Sedangkan pengaruh DSRI (Days Sales In Receivable Index), AQI (Asset Quality Index) dan DEPI
(Depreciation Index) secara parsial atau secara masing-masing tidak berhasil menunjukan mempunyai pengaruh yang signifikan terhadap pendeteksian kecurangan laporan keuangan atau fraud.

\section{Saran}

Bagi peneliti selanjutnya yang ingin melakukan penelitian lebih lanjut mengenai pendeteksian kecurangan laporan keuangan menggunakan metode Beneish Ratio Index disarankan untuk menambah model yang lainnya untuk mendeteksi kecurangan laporan keuangan (fraud), misalnya menggunakan model Altman serta memperluas sampel penelitian yang mencakup laporan keuangan perusahaan yang belum atau tidak dinyatakan melakukan kecurangan (fraud), guna membuktikan sejauh mana model (Beneish dan Altman) dapat digunakan secara efektif untuk memprediksi terjadinya kecurangan laporan keuangan perusahaan.

\section{DAFTAR PUSTAKA}

[1] Kompas.com, "Indeks Persepsi Korupsi Indonesia pada 2019 Naik Jadi 40,” 2020. https://nasional.kompas.com/read/ 2020/01/23/16565951/indekspersepsi-korupsi-indonesia-pada2019-naik-jadi-40?page=all. [accessed 07 November 2020]

[2] C. Indonesia, "BEI Ketemu Garuda Selasa, Kontrak dengan Mahata Dipertanyakan,” 2019. https://www.cnbcindonesia.com/m arket/20190426091933-1769018/bei-ketemu-garuda-selasakontrak-dengan-mahata- 
dipertanyakan. [accessed 07 November 2020]

[3] Tempo.co, "Bapepam: Kasus Kimia Farma Merupakan Tindak Pidana," 2003. https://bisnis.tempo.co/read/33339/ bapepam-kasus-kimia-farmamerupakan-tindak-pidana. [accessed 07 November 2020]

[4] W. Hermansyah, "Teknik Mengungkap Tax Fraud," Unair, 2015.

[5] Scoot, R. William. "Financial Accounting Theory". Toronto: Person Prentice Hall, 2015.

[6] Supriyono, R. A, "Akuntansi Keperilakuan”. Yogyakarta: Gadjar Mada University Perss, 2018.

[7] W. S. Albrect, C. C. Albrect, C. O. Albrect, and M. F. Zimbelman, Fraud Examination. USA: SouthWestern Cengage Learning, 2012.

[8] T. M. Tuanakotta, Akuntansi
Forensik dan Audit Investigatif. Jakarta: Salemba Empat, 2012.

[9] S. Munawir, Analisa Laporan Keuangan. Yogyakarta: Liberty, 2014.

[10] D. E. Kieso, J. J. Weygandt, and T. D. Warfield, Intermediate Accounting. Jakarta: Erlangga, 2011.

[11] D. E. Kieso, J. J. Weygandt, and T. D. Warfield, Pengantar Akuntansi 1. Jakarta: Salemba Empat, 2013.

[12] ACFE, Report to The Nation on Occupational Fraud and Abuse 2014 Global Fraud Study. Austin: Association of Certified Fraud Examiners, 2014.

[13] . . Hantono, "Deteksi Financial Statement Fraud Melalui Model Beneish Pada Perusahaan Bumb," JMBI UNSRAT (Jurnal Ilm. Manaj. Bisnis dan Inov. Univ. Sam Ratulangi)., vol. 5, no. 3, pp. 135150, 2018, doi: 10.35794/jmbi.v5i3.21705. 